\title{
C-reactive protein as an inflammatory marker of acute infections outside intensive care settings: case report and evidence-based literature review
}

Alcino Pires Gama ${ }^{a}$ Itamar de Souza Santos ${ }^{a}$, Rodrigo Diaz Olmos ${ }^{a, b}$, Lucia Mendes de Oliveira Pinto ${ }^{b}$, Isabela Judith Martins Benseñor ${ }^{a}$, Paulo Andrade Lotufo ${ }^{a}$

Gama AP, Santos IS, Olmos RD, Pinto LMO, Benseñor IJM, Lotufo PA. C-reactive protein as an inflammatory marker of acute infections outside intensive care settings: case report and evidence-based literature review. Autopsy Case Rep [Internet]. 2011;1(4):3-9. http://dx.doi.org/10.4322/acr.2011.011

\section{ABSTRACT}

We present the clinical case of a 76-year-old woman with delirium caused by multiple factors, including pneumonia. Although this type of case is quite common in clinical practice, it provides us with an opportunity to discuss laboratory testing in this context, with a special focus on the role of C-reactive protein (CRP). We present data regarding the requests for determination of serum CRP levels at the University of São Paulo University Hospital over the past few years. We also present a review of the medical literature on the topic, as well as clinical epidemiology concepts related to the impact that CRP testing has on the medical decision-making process.

Keywords: C-reactive protein; Internal medicine; Diagnostic techniques and procedures.

\section{INTRODUCTION}

The objective of the present case report is to describe a common situation in the treatment of patients with acute community-acquired infections at a university hospital. We also present a critical evaluation of the ordering and interpretation of the results of tests to determine serum levels of $\mathrm{C}$-reactive protein (CRP) as an inflammatory marker in this context.

\section{METHODS}

We selected the case of a patient treated at the University of São Paulo University Hospital (USPUH) Emergency Department, located in the city of São
Paulo, Brazil. We performed a retrospective analysis of the medical chart of the patient in an attempt to determine whether the determination of serum CRP levels was necessary for the management of the case.

The present case report was approved by the local research ethics committee.

\section{CLINICAL CASE}

A 76-year-old woman sought treatment in the USPUH Emergency Department with a 3-day history of hypoactivity and loss of appetite. The patient reported that she had experienced a drop in

\footnotetext{
a Department of Internal Medicine - Faculdade de Medicina - Universidade de São Paulo, São Paulo/SP - Brazil.

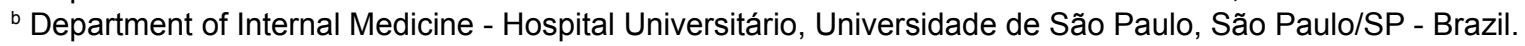

Copyright $\odot 2011$ Autopsy and Case Reports - This is an Open Access article distributed of terms of the Creative Commons Attribution NonCommercial License (http://creativecommons.org/licenses/by/3.0/) which permits unrestricted non-commercial use, distribution, and reproduction in any médium provided article is properly cited. 
the level of consciousness on the previous day. She also reported that she had fallen from standing height 15 days prior to the onset of the symptoms.

The patient had a personal history of chronic obstructive pulmonary disease and had been on home oxygen therapy for the last six years. She reported that she did not have arterial hypertension or diabetes and had experienced no cardiovascular events. The patient had a family history of cancer, her father having died at age 52 years from carcinoma of the oropharynx and her mother having died from cancer, the primary site of which was unknown to the patient.

Physical examination revealed dehydration, pallor, cyanosis, and extensive ecchymosis on the right side of the face. The patient presented with spatiotemporal disorientation (Glasgow coma scale score, 13). Her temperature was $36^{\circ} \mathrm{C}$, her blood pressure was $90 / 50 \mathrm{mmHg}$, her heart rate was $90 \mathrm{bpm}$, and her peripheral oxygen saturation was $68 \%$ on room air. There were no signs or symptoms of heart disease, lung disease, or abdominal disease. In addition, there were no signs or symptoms of upperor lower-limb disorders. Her capillary blood glucose level was $80 \mathrm{mg} \cdot \mathrm{dL}^{-1}$.

A presumptive diagnosis of hypoactive delirium was made, and tests were ordered (Table 1). A bedside chest X-ray was taken. Although it is technically difficult to interpret chest X-rays taken under such conditions, the findings were suggestive of a focus of infection in the right lung base (Figure 1). Because the information in the medical chart of the patient had been constantly updated, it was possible to compare the results of the arterial blood gas analysis performed at admission with those of that performed in 2004.

The patient underwent aggressive hydration with saline solution. She was diagnosed with pneumonia (a PORT score of 236, risk class V) and exacerbation of chronic obstructive pulmonary disease. She was started on empirical treatment with $2 \mathrm{~g} /$ day of ceftriaxone. On the following day, clarithromycin (500 mg every 12 hours) was added. Her level of consciousness improved, as did her renal function and leukocyte count.

\section{DISCUSSION}

An acute phase protein, CRP is generally found at high levels during inflammatory processes of various etiologies, including those of an infectious, autoimmune, or traumatic nature. The protein was
Table 1 - Laboratory tests performed in the Emergency Department

\begin{tabular}{|c|c|c|}
\hline Laboratory test & Results & Reference Value \\
\hline Hemoglobin & 11.0 & $12.3-15.3 \mathrm{~g} / \mathrm{dl}$ \\
\hline Hematocrit & 32 & $36.0-45.0 \%$ \\
\hline $\begin{array}{l}\text { Mean } \\
\text { corpuscular } \\
\text { volume }\end{array}$ & 90 & $80-96 \mathrm{fl}$ \\
\hline $\begin{array}{l}\text { Mean } \\
\text { corpuscular } \\
\text { hemoglobin }\end{array}$ & 31 & 27.5-33.2 pg \\
\hline White blood cells & 14.7. $10^{3}$ & $4.4-11.3 \cdot 10^{3} / \mathrm{mm}^{3}$ \\
\hline \begin{tabular}{l}
\multicolumn{1}{c}{ Bands } \\
Segmented \\
neutrophils
\end{tabular} & $\begin{array}{l}10 \\
88\end{array}$ & $\begin{array}{c}1-5(\%) \\
45-70(\%)\end{array}$ \\
\hline Platelets & 147. $10^{3}$ & $\begin{array}{c}150-400 \cdot 10^{3} \\
\left(/ \mathrm{mm}^{3}\right)\end{array}$ \\
\hline Urea & 105 & $10-50(\mathrm{mg} / \mathrm{dl})$ \\
\hline Creatinin & 1.0 & $0.4-1.3(\mathrm{mg} / \mathrm{dl})$ \\
\hline Sodium & 126 & $135-146(\mathrm{mEq} / \mathrm{l})$ \\
\hline Potassium & 4.6 & $3.5-5.0(\mathrm{mEq} / \mathrm{l})$ \\
\hline Ionized calcium & 0.96 & $1.1-1.4(\mathrm{mmol} / \mathrm{l})$ \\
\hline $\begin{array}{c}\text { Aspartate } \\
\text { aminotransferase }\end{array}$ & 21 & $10-35(\mathrm{U} / \mathrm{l})$ \\
\hline $\begin{array}{c}\text { Alanine } \\
\text { aminotransferase }\end{array}$ & 13 & $9-43(\mathrm{U} / \mathrm{l})$ \\
\hline $\begin{array}{l}\text { Prothrombin time } \\
\text { (International } \\
\text { Normalized } \\
\text { Ratio - INR) }\end{array}$ & 1.04 & 1 \\
\hline Urinalysis & $\begin{array}{c}\mathrm{pH}=5.5 \\
6,000 \\
\text { leukocytes } / \mathrm{ml} \\
1,000 \\
\text { erythrocytes } / \mathrm{ml}\end{array}$ & $\begin{aligned} & 4.7-7.8 \\
< & 10000 / \mathrm{mm}^{3} \\
< & 10000 \mathrm{~mm}^{3}\end{aligned}$ \\
\hline $\begin{array}{l}\text { Arterial blood } \\
\text { gases } \\
\text { (room air) }\end{array}$ & $\begin{array}{c}\mathrm{pH}=7.32 \\
\mathrm{pO}_{2}=32 \\
\mathrm{pCO}_{2}=61 \\
\text { Bicarbonate }=31 \\
\text { Base Excess }=+3.7 \\
\text { Arterial } \mathrm{O}_{2} \text { sat }=66\end{array}$ & $\begin{array}{c}7.34-7.44 \\
75-100 \mathrm{mmHg} \\
35-45 \mathrm{mmHg} \\
22-26 \mathrm{mEq} / \mathrm{l} \\
-3-+2.3 \mathrm{mEq} / \mathrm{l} \\
95-98 \%\end{array}$ \\
\hline $\begin{array}{l}\text { C-reactive } \\
\text { protein }\end{array}$ & 149 & $<5(\mathrm{mg} / \mathrm{l})$ \\
\hline
\end{tabular}

first described in 1930, having been isolated from the serum of patients with bacterial pneumonia. ${ }^{1}$ The physiological role of CRP is related to the ability of the protein to bind to cell wall components of various microorganisms, thus activating the classical complement pathway, acting as an opsonin and promoting phagocytosis. ${ }^{2,3}$

The determination of serum CRP levels has recently been described as playing a role in the treatment of intensive care unit patients with septic 


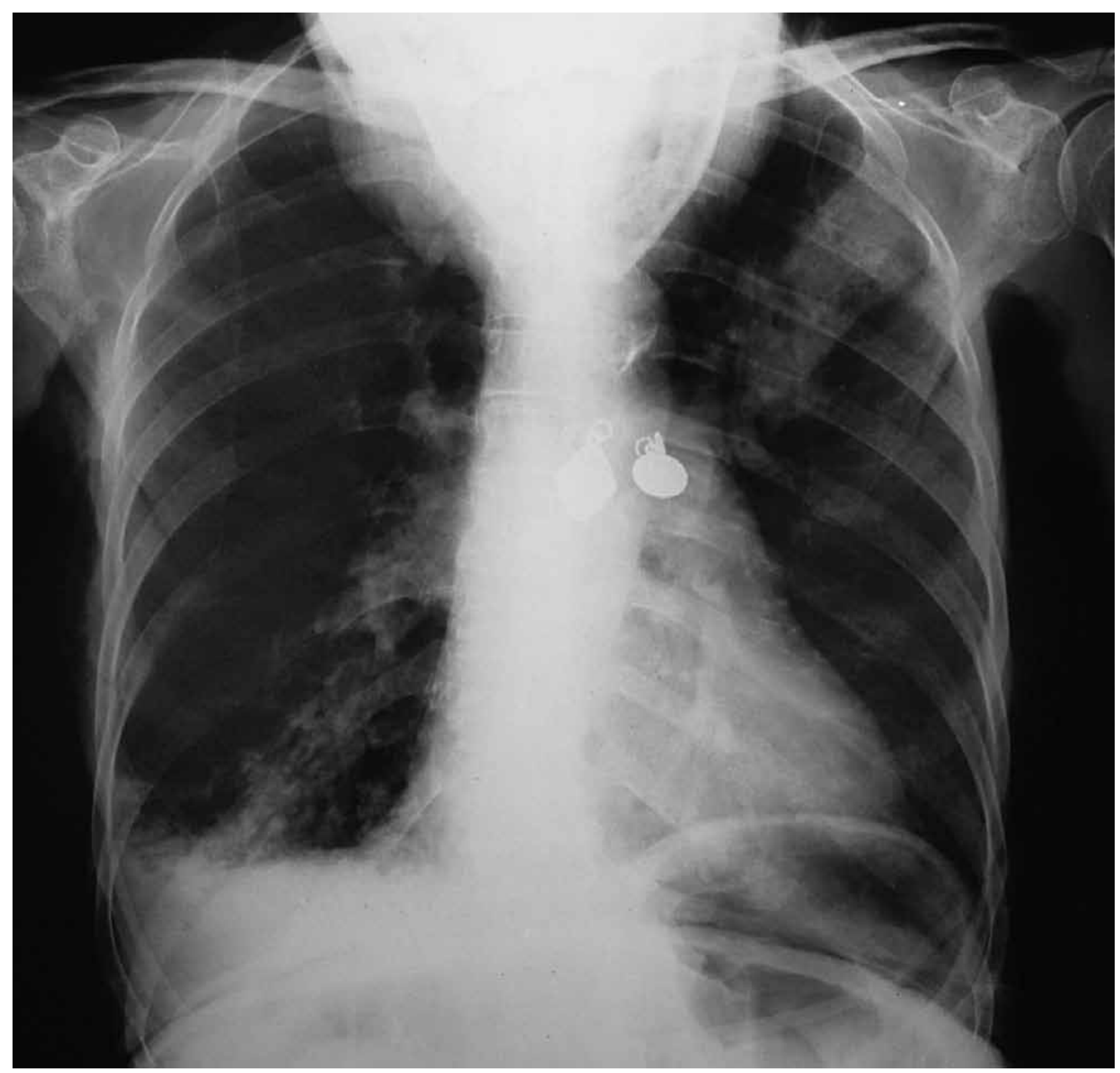

Figure 1 - Chest X-Ray showing heterogeneous opacity in right lung base and right costophrenic angle blurring, compatible with pneumonia.

shock $^{4,5}$ and in the prognosis of cardiovascular diseases (when high-sensitivity CRP is assessed), ${ }^{6,7}$ as well as being a prognostic and diagnostic marker in patients with specific infectious diseases. The use of CRP testing in the follow-up of patients with infectious diseases outside the intensive care setting has yet to be standardized. Although the single determination of serum CRP levels is unexpensive, its indiscriminate use results in high costs, which is why standardization is required.

\section{The Situation at the USPUH}

The USPUH is a community hospital that is dedicated to the care of Butantã residents, USP staff, and USP students. In recent years, the number of requests for determination of serum CRP levels in the USPUH, more specifically in the emergency department and in the clinical ward, has increased considerably. This increase was not accompanied by a proportional increase in the number of consults and hospitalizations.

The estimated cost of the reagent for each CRP test in the USPUH is R $\$ 9.22$ (approximately US $\$ 5.00)$. Taking into account the costs related to the repetition of the test in cases of abnormal results, as well as those related to materials and others, the annual cost of the determination of serum CRP levels is approximately $R \$ 330,000.00$ (US $\$ 185,000.00$ ). 
Here, we present a discussion of two studies that aimed at establishing the potential impact of the determination of serum CRP levels on the evaluation and treatment of patients suspected of having acute community-acquired infection. We also revisit certain clinical epidemiology concepts, which are required in order to interpret the results.

\section{Highlights of our Review of the Literature on the use of CRP as a Marker of Inflammation for Patients in the Emergency Department}

Study no. 1 - Prognostic value of mortality in emergency department sepsis score, procalcitonin, and C-reactive protein in patients with sepsis at the emergency department ${ }^{8}$.

That study compared the relationship between early mortality (0-5 days) and late mortality (6-30 days) of patients with sepsis initially evaluated in the emergency department. Three different tests, performed at admission to the emergency department, were compared:

- determination of serum CRP levels;

- determination of serum procalcitonin levels;

- Mortality in Emergency Department Sepsis (MEDS) score $^{9}$, a clinical and laboratory scoring system (Table 2).

It is clear that the major part of the score (and therefore the greatest weight) is attributed to anamnesis and clinical examination. In addition, the laboratory tests employed (blood workup and, in the presence of signs of respiratory infection, chest X-rays) are those that are habitually ordered in order to evaluate patients with sepsis.

The authors determined the cut-off point that was most accurate for each of the three evaluations. Sensitivity and specificity values (described below) were used in that study in order to calculate positive and negative likelihood ratios ( $L R+$ and $L R-$, respectively).

The LR+ expresses how many times a positive result of a given test is more likely to be found in individuals with a given disease than in those without it. The ratio between true positives and false positives is therefore calculated. The LR-expresses how many times a negative result of a given test is more likely to be found in individuals with a given disease (false negatives) than in those without it. Similarly, the ratio between false negatives and true negatives is calculated (Chart 1).

For a test that is more frequently positive in patients with a given disease and more frequently negative in those without it, as is common in clinical practice, the LR+ is a number greater than 1 and the LR- is a number between 0 and 1 . A greater distance from the number 1 translates to a greater impact of the test on the clinical reasoning (Chart 1).

Table 2 - MEDS scoring system. Adapted form Lee et al. ${ }^{8}$

\begin{tabular}{cc}
\hline Clinical variable & Score \\
\hline Terminal illness & 6 \\
Tachypnea or hypoxia & 3 \\
Septic shock & 3 \\
Platelets $<150.000 / \mathrm{mm}^{3}$ & 3 \\
Bands $>5 \%$ & 3 \\
Age $>65$ anos & 3 \\
Low respiratory tract infection & 2 \\
Nursing home resident & 2 \\
Altered mental status & 2 \\
Total & 27 \\
\hline
\end{tabular}

Chart 1 - How to calculate LR+, LR- and how to interpret test results. Adapted from Hatanaka. ${ }^{10}$

\begin{tabular}{|c|}
\hline How to calculate LR+: \\
\hline Probability of positive test in individuals with disease \\
\hline Probability of positive test in individuals without disease \\
\hline How to calculate LR-: \\
\hline Probability of negative test in individuals with disease \\
\hline Probability of negative test in individuals without disease \\
\hline$L R>10.0$ or $L R<0.1$ \\
\hline Very good test, almost always impacts on clinical judgement \\
\hline$L R$ 5.0-10.0 or $0.1-0.2$ \\
\hline Intermediate test value, can impact on clinical judgement \\
\hline$L R 2.0-5.0$ or $0.2-0.5$ \\
\hline Weak test, seldom changes clinical judgement \\
\hline$L R$ 0.5-2.0 \\
\hline $\begin{array}{l}\text { Test is incapable of changing clinical judgement, it must not } \\
\text { be performed' }\end{array}$ \\
\hline
\end{tabular}


In clinical epidemiology terms, a greater distance between the LR and the number 1 translates to a greater impact of that result on the likelihood that the patient will have the disease (post-test probability). Fagan's nomogram is used in order to illustrate this concept, as in our Figure 2. The figure shows the case of a patient who, before the test, has a $10 \%$ chance of having the disease (pre-test probability). If that patient undergoes a diagnostic test with a LR+ of 1.5 , which confirms that result, the probability of having the disease increases to approximately $14 \%$. However, if the patient undergoes a test with a LR+ of 5 or 15 , the post-test probability is 35.7 and $62.5 \%$, respectively.

Let us return to study no. $1^{8}$ in order to analyze the results of the comparison between the determination of serum CRP levels and the MEDS score in terms of their performance (Table 3). The determination of serum CRP levels is clearly inferior to the use of the MEDS score. The CRP-related PLR for early mortality has little influence on the evaluation of disease severity. More specifically, a high MEDS score at admission to the emergency department constitutes a far stronger indicator of disease severity and risk of death than do high serum CRP levels.

Study no. 2 - Diagnostic value of $C$ reactive protein in infections of the lower respiratory tract: systematic review. ${ }^{11}$

Study no. 2, published in the British Medical Journal, presents the results of a systematic review of the literature evaluating the diagnostic accuracy of CRP testing in detecting radiologically proved pneumonia, as well as the extent to which the CRP test results can allow the reader to differentiate between viral and bacterial infections of the lower respiratory tract. Regarding the diagnostic accuracy of CRP testing in detecting radiologically proven pneumonia, the authors found six studies, a total

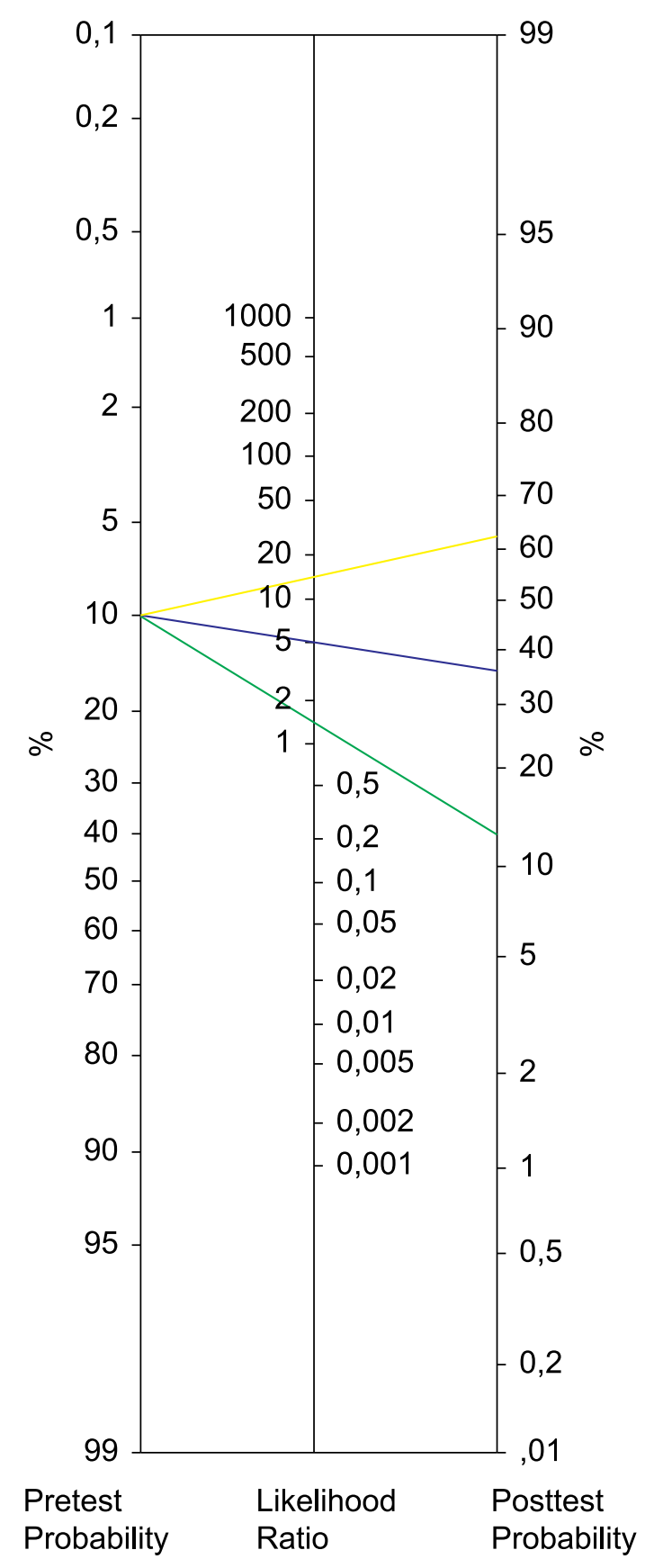

Figure 2 - Fagan's nomogram. Lines indicate the impact of three tests, with LRs of 1.5 (green), 5.0 (blue) and 15.0 (yellow), on disease probability of a person with a $10 \%$ pretest probability.

Table 3 - C-reactive protein determination and MEDS score performances to predict early (0-5 days) and late (6-30 days) mortality in sepsis. Adapted form Lee et al. ${ }^{8}$

\begin{tabular}{cccccc}
\hline Early Mortality (0-5 days) & Best cut-off value & Sensitivity & Specificity & LR+ & LR- \\
\hline C-reactive protein & $>70$ mg.dL-1 & $73 \%$ & $63 \%$ & 1.97 & 0.43 \\
MEDS score & $>9$ & $52 \%$ & $93 \%$ & 7.43 & 0.52 \\
\hline Late Mortality (6-30 days) & Best cut-off value & Sensitivity & Specificity & LR+ & LR- \\
\hline C-reactive protein & $>60 ~ \mathrm{mg}_{\mathbf{d L}} \mathrm{dL}^{-1}$ & $64 \%$ & $58 \%$ & 1.52 & 0.62 \\
MEDS score & $>8$ & $46 \%$ & $91 \%$ & 5.11 & 0.59 \\
\hline
\end{tabular}


of 1,178 patients having been evaluated. The determination of CRP levels has little impact on the clinical reasoning involved in the interpretation of infiltration seen on X-rays. For a cut-off point of $20 \mathrm{mg}$. $\mathrm{dL}^{-1}$ (the point of highest accuracy), the CRP test LR+ (2.86), LR- $(0.28)$, sensitivity $(80 \%)$, and specificity $(72 \%)$ were shown to have little impact on clinical practice, and decisions based on those results might lead to errors in a significant number of cases.

Eight studies were deemed appropriate to evaluate whether CRP was able to differentiate between viral and bacterial infections of the lower respiratory tract.

The studies in question were quite heterogeneous in terms of methodology.

The authors concluded that "the current evidence does not consistently and sufficiently support a wide introduction of CRP as a rapid test to guide antibiotics prescription".

\section{FINAL CONSIDERATIONS}

In the clinical case reported here, as occurs in many others, the determination of serum CRP levels did not aid in estimating the severity of the condition of the patient or in selecting medical approaches to management. It is of note that neither the decisions that were made nor the outcome would have changed had the test not been ordered.

Requests for unnecessary tests result in material and human costs. It is important to maximize efforts to avoid such costs. The responsibility is even greater in the context of a teaching hospital. In addition, the possibility of making decisions based on the result of a laboratory test while there is still insufficient scientific evidence to support its use is a cause for concern. This evidence-based reasoning is quite common when selecting the therapeutic approach to a given patient. However, for some reason, the decision regarding which laboratory tests should be ordered is not always evidence-based. It is incorrect to assume that, unlike the administration of drugs, ordering unnecessary tests is not harmful to patients. False-positive results, which are inherent to any ancillary test, can lead to invasive diagnostic strategies and incorrect treatments.

In adults, CRP has certain well-established roles, such as in the outpatient follow-up treatment of connective tissue diseases and certain chronic infections. In the follow-up of patients with acute infections, CRP plays a potential role in intensive care patients, which is due to the multiple variables involved. Such patients are at risk of developing nosocomial infections, undergo multiple procedures, and are exposed to various factors that can worsen the clinical profile. Nevertheless, serum CRP levels can never be considered in isolation and can be normal even in patients with severe infection, especially at the early stages.

For patients admitted to the emergency department or infirmary, where the objective is to diagnose and provide initial treatment for the infection, CRP has little impact on the clinical reasoning. The use of the test can even lead to a false sense of security and deprive patients with bacterial disease of the appropriate treatment. There is also no evidence to support the use of the test in patient follow-up. In addition, it is of note that the first-line treatment for the acute bacterial infections that are most common in clinical practice is likely to yield a favorable result. When this does not occur, clinical signs are generally sufficient to detect treatment failure.

The data presented here underscore the need for coordinated efforts in order to rationalize the use of resources. In a teaching hospital, the attending physician has the responsibility of teaching medical students and residents the principles of good medical practice. This includes teaching the value of anamnesis and clinical examination in order to avoid submitting patients to unnecessary tests.

\section{REFERENCES}

1. Tillet WS, Francis T. Serological reactions in pneumonia with a non-protein somatic fraction of pneumococcus. J Exp Med. 1930;52:561-71. PMid:19869788. PMCid:2131884. http://dx.doi.org/10.1084/jem.52.4.561

2. Du Clos TW. Functions of C-reactive protein. Ann Med. 2000;32:274-8. PMid:10852144. http://dx.doi. org/10.3109/07853890009011772

3. Casey R, Newcombe J, McFadden JJ, Bodman-Smith KB. The acute-phase reactant C-reactive protein binds to phosphorylcholine-expressing Neisseria meningitidis and increases uptake by human phagocytes. Infect Immun. 2008;76:1298-304. PMid:18195032. PMCid:2258818. http://dx.doi.org/10.1128/IAI.00741-07 
4. Povoa P, Coelho L, Almeida E, et al. Early identification of intensive care unit-acquired infections with daily monitoring of C-reactive protein: a prospective observational study. Crit Care. 2006;10:R63. PMid:16635270. PMCid:1550913. http://dx.doi.org/10.1186/cc4892

5. Fraunberger $\mathrm{P}$, Wang $\mathrm{Y}$, Holler $\mathrm{E}$, et al. Prognostic value of interleukin-6, procalcitonin and c-reactive protein levels in intensive care unit patients during first increase of fever. Shock. 2006;26:10-2. PMid:16783191. http:// dx.doi.org/10.1097/01.shk.0000215319.06866.bd

6. Ridker PM, Danielson E, Fonseca FAH, et al. Rosuvastatin to prevent vascular events in men and women with elevated c-reactive protein. N Engl J Med. 2008;359:2195-207. PMid:18997196. http://dx.doi.org/10.1056/NEJMoa0807646

7. Ridker PM, Paynter NP, Rifai N, Gaziano JM, Cook NR. C-reactive protein and parental history improve global cardiovascular risk prediction: the Reynolds risk score for men. Circulation. 2008;118:2243-51. PMid:18997194. PMCid:2752381. http://dx.doi.org/10.1161/ CIRCULATIONAHA.108.814251
8. Lee C-C, Chen S-Y, Tsai C-L, et al. Prognostic value of mortality in emergency department sepsis score, procalcitonin, and C-reactive protein in patients with sepsis at the emergency department. Shock. 2008;29:322-7. PMid:17724429. http:// dx.doi.org/10.1097/SHK.0b013e31815077ca

9. Carpenter CR, Keim SM, Upadhye S, Nguyen HB. Best Evidence in Emergency Medicine Investigator Group. Risk stratification of the potentially septic patient in the emergency department: the Mortality in the Emergency Department Sepsis (MEDS) score. J Emerg Med. 2009;37:319-27. PMid:19427752. http://dx.doi. org/10.1016/j.jemermed.2009.03.016

10. Hatanaka VMA, Benseñor IM. Avaliação de testes diagnósticos. In: Benseñor IM, Lotufo PA, editors. Epidemiologia: abordagem prática. 2nd ed. São Paulo: Sarvier; 2011. p. 272-302. Portuguese.

11. Van der Meer V, Neven AK, Van Den Broek PJ, Assendelft WJJ. Diagnostic value of $C$ reactive protein in infections of the lower respiratory tract: systematic review. Br Med J. 2005;331:26. http://dx.doi.org/10.1136/bmj.38483.478183

\title{
Conflict of interest: None
}

Submitted on: $18^{\text {th }}$ October 2011

Accept on: $24^{\text {th }}$ October 2011

\author{
Correspondence: \\ Alcino Pires Gama \\ Rua Ovídio Pires de Campos, 171/217 - Cerqueira Cesar - São Paulo - SP - Brazil \\ CEP: 05403-010 - Phone: +55 (011) 7039-1514 \\ E-mail: alcinopires@yahoo.com.br
}

